\title{
EFFECTS OF FUNGICIDES ON THE DEVELOPMENT OF THE ENTOMOPATHOGENIC FUNGUS Metarhizium anisopliae VAR. anisopliae
}

\author{
Maribel Yáñez ${ }^{1}$, and Andrés France ${ }^{1 *}$
}

\begin{abstract}
Metarhizium anisopliae (Metschnikoff) Sorokin is an entomopathogenic fungus used for controlling different insect pests. It is most frequently applied to berry fruit crops, where fungicides are also used for disease control. Fungicides: azoxystrobin, benomyl, captan, chlorothalonil, fenhexamid, fludioxonil, iprodione, and metalaxyl in concentrations of $0.01,0.1,1.0,10$, and $100 \mathrm{mg} \mathrm{L}^{-1}$ were evaluated in this research study. Vegetative growth, conidia germination, and conidia germination tube length were measured on the Qu-M82, Qu-M151b, Qu-M253, Qu-M430, and QuM984 Metarhizium anisopliae var. anisopliae fungus strains. Those strains were selected because of their present use against different insect pest in bramble fruits. Vegetative growth was measured through the colony rate growth in agar media, and those reaching up to $50 \%$ of the check growth were considered compatible. Results indicate that the benomyl and fenhexamid fungicides were compatible with the five isolates whereas, azoxystrobin and fludioxonil were incompatible. Furthermore, benomyl and fludioxonil reduced conidia germination by 53 and $91 \%$, and germination tube length by 18 and $37 \%$, respectively.
\end{abstract}

Key words: biological control, integrated management, fungal growth, conidia germination.

\section{INTRODUCTION}

Many insect pests are susceptible to infections produced by entomopathogenic fungi (EF), some of which have been studied for use as mycoinsecticides since they are insect-specific and safe to animals and plants (Kaya and Lacey, 2007). Among the most studied insect pathogenic fungi species are Hyphomycetes Beauveria bassiana, Metarhizium anisopliae (Metschnikoff) Sorokin, and Verticillium lecanii (Khetan, 2001). EF efficiency can be affected by numerous coactions of biotic and abiotic factors: desiccation, UV light, host behavior, temperature, entomopathogen vigor, host condition, and agrochemical effects (Flexer and Belnavis, 2000; Inglis et al., 2006). Plant protection products acting on EF can vary as a function of the species and EF structure type, chemical nature of the product, and doses used. Effects decrease vegetative growth and germination, as well as genetic mutations, virulence, including EF death (Alves et al., 1998).

Fungicides are among the products frequently used

${ }^{1}$ Instituto de Investigaciones Agropecuarias INIA, Casilla 426, Chillán, Chile. *Corresponding author (afrance@inia.cl).

Received: 06 May 2009.

Accepted: 12 October 2010. in agriculture that would theoretically act directly on EF. However, there is background information about the different degrees of EF fungicide tolerance. Rebollar et al. (1996) reported that benomyl and mancozeb showed a high degree of growth inhibition of Verticillium lecanii fungus. Durán et al. (2004) mention that benomyl, dimethomorph-mancozeb, chlorothalonil, propineb, mancozeb, and mancozeb-cymoxanil mixture fungicides significantly affect germination and growth of $B$. bassiana while fosetyl-Al, propamocarb, and copper oxychloride do not.

Using EF to control important agricultural pests is relatively recent in Chile and its application has emphasized berry pest control in both organic and conventional management (Devotto and Gerding, 2001). Therefore, there are cases where applying EF is prior to or follows the application of frequently used fungicides to control disease and which are registered for berries. It is not known what effect these products can have on EF which are actually being used for biological control of berry pests such as multiple strains of Metarhizium anisopliae. Consequently, the objective of this study was to determine the effect of allowed fungicides in berries on conidia germination and vegetative growth of the $M$. anisopliae var. anisopliae fungus. 


\section{MATERIALS AND METHODS}

\section{Fungicide selection}

Registered commercial fungicides for blueberries (Vaccinium corymbosum L.), raspberries (Rubus idaeus L.), strawberries (Fragaria chiloensis Duch.), blackberries (hybrids of Rubus spp.), and zarzaparillas (Ribes trilobum Meyen) were selected to carry out the bioassays in the 2008-2009 season. Furthermore, these fungicides were allowed for fruit destined to the United States, Japan, and European Union markets (Asociación de Exportadores de Chile, 2008). These products were: azoxystrobin (methyl (E)-2-\{2-[6-(2-cyanophenoxy) pyrimidin-4-yloxy]phenyl $\}-3-m e t h o x y a c r y l a t e)$, benomyl (methyl 1-(butylcarbamoyl)benzimidazol2-ylcarbamate), captan ( $N$-(trichloromethylthio) cyclohex-4-ene-1,2-dicarboximide), chlorothalonil (tetrachloroisophthalonitrile), fenhexamid ( $2^{\prime}, 3^{\prime}$-dichloro4'-hydroxy-1-methylcyclohexanecarboxanilide), fludioxonil (4-(2,2-difluoro-1,3-benzodioxol-4-yl)- $1 \mathrm{H}$ pyrrole-3-carbonitrile), iprodione(3-(3,5-dichlorophenyl)$N$-isopropyl-2,4-dioxoimidazolidine-1-carboxamide), and metalaxyl (methyl $N$-(methoxyacetyl)- $N$-(2,6-xylyl)DL-alaninate).

\section{Strain selection and multiplication}

Five frequent strains of $M$. anisopliae var. anisopliae, which have demonstrated their effectiveness in distinct economically important pests affecting berries, were employed (Table 1). These strains were selected from the EF collection of the Instituto de Investigaciones Agropecuarias (INIA), Quilamapu, Chillán originally obtained from a country-wide prospection since 1996 and maintained in cryopreservation (France et al., 2000).

Each of the strains mentioned (Table 1) was thawed from liquid $\mathrm{N}$ and plated in tubes with potato dextrose agar (PDA, Difco, Detroit, Michigan, USA). Conidia were then collected with a bacteriological loop and superficially spread on $80 \mathrm{~mm}$ diameter Petri dishes with PDA medium. Dishes were incubated at $25^{\circ} \mathrm{C}$ for 4 to $5 \mathrm{~d}$ until multiple colonies developed in such a way as to allow extracting $5 \mathrm{~mm}$ diameter mycelium disks. These disks were sown again on Petri dishes with PDA and incubated at $25^{\circ} \mathrm{C}$ for $10 \mathrm{~d}$. At the end of this incubation period, fungal material obtained was employed to evaluate the relative growth of the colonies. The plating procedure was carried out under sterile conditions in a laminar flow chamber.

\section{Effect of fungicides on the relative growth of colonies}

The preparation of media was carried out in flasks with a concentration of $39 \mathrm{~g} \mathrm{~L}^{-1} \mathrm{PDA}$; agar was dissolved in a microwave for $10 \mathrm{~min}$ and then sterilized for $20 \mathrm{~min}$. Afterward, media were cooled and when temperature approached $60^{\circ} \mathrm{C}$, fungicides were incorporated separately in concentrations of $0.01 ; 0.1 ; 1.0 ; 10$, and $100 \mathrm{mg} \mathrm{L}^{-1}$ of active ingredient (Lennox and Spotts, 2003; Tremblay et al., 2003; Samson et al., 2005). PDA supplemented with distinct fungicide concentrations was poured onto Petri dishes ( $80 \mathrm{~mm}$ diameter) and once the medium solidified, a $5 \mathrm{~mm}$ diameter cylinder was extracted from the center of each dish with a lab scoop.

Disks with a $5 \mathrm{~mm}$ diameter were extracted from the edge of the growth of incubated dishes, during the strain multiplication stage, and when the colony advanced up to half the dish radius. These disks replaced a cylinder of the same size, like the one taken from the dishes

Table 1. Origin (latitude and longitude) and pest controlled by Metarhizium anisopliae var. anisopliae isolates used in assays.

\begin{tabular}{lll}
\hline Isolate & \multicolumn{1}{c}{$\begin{array}{c}\text { Origin (latitude and } \\
\text { longitude) }\end{array}$} & \multicolumn{1}{c}{ Controlled pest } \\
\hline Qu-M82 & $\begin{array}{l}\text { El Carmen } \\
\left(36^{\circ} 53,17.0^{\prime} \mathrm{S} ; 72^{\circ} 0,18.29 ” \mathrm{~W}\right)\end{array}$ & $\begin{array}{l}\text { Naupactus xantographus (South American fruit tree } \\
\text { weevil) }\end{array}$
\end{tabular}

Qu-M151b

Río Chamiza

(41'6'50.47” S; 7249’3.44”'W)

Qu-M253

Entre Lagos

(40³4'29.78” S; 7302'37.63” W)

Qu-M430

Osorno

(40³4'29.78” S; 7302'37.63” W)

Qu-M984
Quillota

(3252'49.38” S; 71¹4'52.14” W)
Otiorhynchus sulcatus (Black vine weevil)

Leptoglossus chilensis (Brown Chilean leaf-footed bug) Nezara viridula (Southern green stink bug)

Aegorhinus superciliosus (Raspberry weevil)

Pseudococcus viburni (Obscure mealybug)

Source: Database Colección de Recurso Genético Microbiano, Centro Tecnológico de Control Biológico, Instituto de Investigaciones Agropecuarias INIA, Chillán, Chile. 
containing PDA supplemented with fungicides. Dishes were incubated in the same conditions as in the previous stage. Colony diameter was measured every $48 \mathrm{~h}$ on four equidistant radii previously marked on the bottom of each dish. Measurements were suspended when the first colony reached the edge of the dish (Köller and Wilcox, 2001; Jobin and Carisse, 2007).

Relative growth of the colonies (RG) was calculated from the data for each strain, fungicide, and concentration. RG was calculated as the area of colony growth in the medium with an active ingredient divided by the area of the colony developed in PDA without fungicides, and this result was multiplied by 100 according to the formula used by Köller and Wilcox (2001), Jobin and Carisse (2007):

$$
\mathrm{RG}=\frac{\begin{array}{c}
\text { Area of colony developed in } \\
\text { PDA with active ingredient }
\end{array}}{\begin{array}{c}
\text { Area of colony developed } \\
\text { in PDA }
\end{array}} \times 100
$$

Strains showing RG equal to or less than 50 were considered incompatible for the evaluation (Köller and Wilcox, 2001; Jobin and Carisse, 2007). Subsequently, the growth rate for each active ingredient, concentration, and strain was calculated for these colonies. These results established the area under the growth inhibition curve (AUGIC), values which were then submitted to ANOVA, comparison, and separation of means with the Tukey test $(\mathrm{P}<0.05)$ by the Infostat $(2002)$ statistical program to compare strains and fungicides. A completely randomized experimental design with three replicates for each fungicide strain and concentration was applied (Fry, 1993).

\section{Effects of fungicides on conidia germination and germination tube length}

Growth rates for each isolate, fungicide, and concentration were calculated with colony diameter data. A linear regression with the OrigenPro (2003) software was carried out on the data, adjusting two types of curves sigmoid and exponential depending on the different strain responses to distinct active ingredients (Fry, 1993). Similarly, a response curve and associated equation were obtained for each isolate and fungicide. Curve values for each strain and those fungicides that showed values less than or equal to $50 \%$ of the maximum of the growth curve were observed and the inhibitory concentration (IC50) was calculated.

The effect of the fungicides on conidia germination was determined by conidia produced in vitro of the different strains to which distilled sterile water was added, diluting each solution to a concentration of $1 \times 10^{5}$ conidia $\mathrm{mL}^{-1}$ (Hänbler and Pontzen, 1999). A 1 mL conidia suspension of each strain was then inoculated, homogeneously distributed on Petri dishes with PDA supplemented with the IC50 corresponding to each strain and fungicide, whereas the control was a Petri dish with only PDA. Dishes were incubated in the same conditions as in the previous assays.

Conidia germination was interrupted after $24 \mathrm{~h}$ of incubation by adding $1 \mathrm{~mL}$ of $70 \%$ lactic acid to each dish. A germination count was then carried out considering only those conidia that exhibited germination tube lengths equal to or greater than conidia length. Conidia and germination tube count and measurement were performed with a compound microscope (Eclipse 80i, Nikon, Nikon Corporation, Japan) and the NIS Elements (2006). Results were expressed as a percentage of germination.

This assay had a completely random design with three replicates, and the experimental unit consisted of 100 conidia. Germination and germination tube length results were submitted to ANOVA, comparison, and separation of means by Student's t-test $(\mathrm{P}<0.05)$. To normalize germination percentage data before ANOVA, an angular transformation was carried out according to the methodology used by Fry (1993).

\section{RESULTS AND DISCUSSION}

\section{Effect of fungicides on relative growth of colonies}

The Qu-M82, Qu-M151b, Qu-M253, and Qu-M984 isolates showed RG lower than 50 beginning with the $0.1 \mathrm{mg} \mathrm{L}^{-1}$ concentration of azoxystrobin. Qu-M430 was incompatible only from $1 \mathrm{mg} \mathrm{L}^{-1}$ and showed the lowest value $(\mathrm{P}<0.05)$ of AUGIC (3.20). The shape of the curves for all isolates addressing this active ingredient were similar, growth decreased as the concentration of active ingredient increased (Figure 1A). The highest value of growth inhibition was recorded for Qu-M82 (AUGIC = 3.72) (Figure 2A). Azoxystrobin belongs to the strobilurin chemical group and accomplishes its fungal action by inhibiting the mitochondrial respiration of fungi, blocking electron transport between cytochrome b and cytochrome $\mathrm{c}_{1}$ where ubiquinol (coenzyme Q) is oxidized, directly interfering with the oxidative phosphorylation process since there would be no more available energy in the mitochondria to synthesize ATP (adenosine triphosphate), and impeding spore germination and pathogen development (Ypema and Gold, 1999; Agrios, 2005; Kanetis et al., 2007). There would therefore be arguments to point out that a lack of energy can affect vegetative development in the studied isolates. Furthermore, there are reports indicating that azoxystrobin is incompatible with EF B. bassiana which is in the same taxonomic family as M. anisopliae (Tamai et al., 2002).

It must be mentioned that comparing AUGIC allows contrasting isolate response with the evaluated 

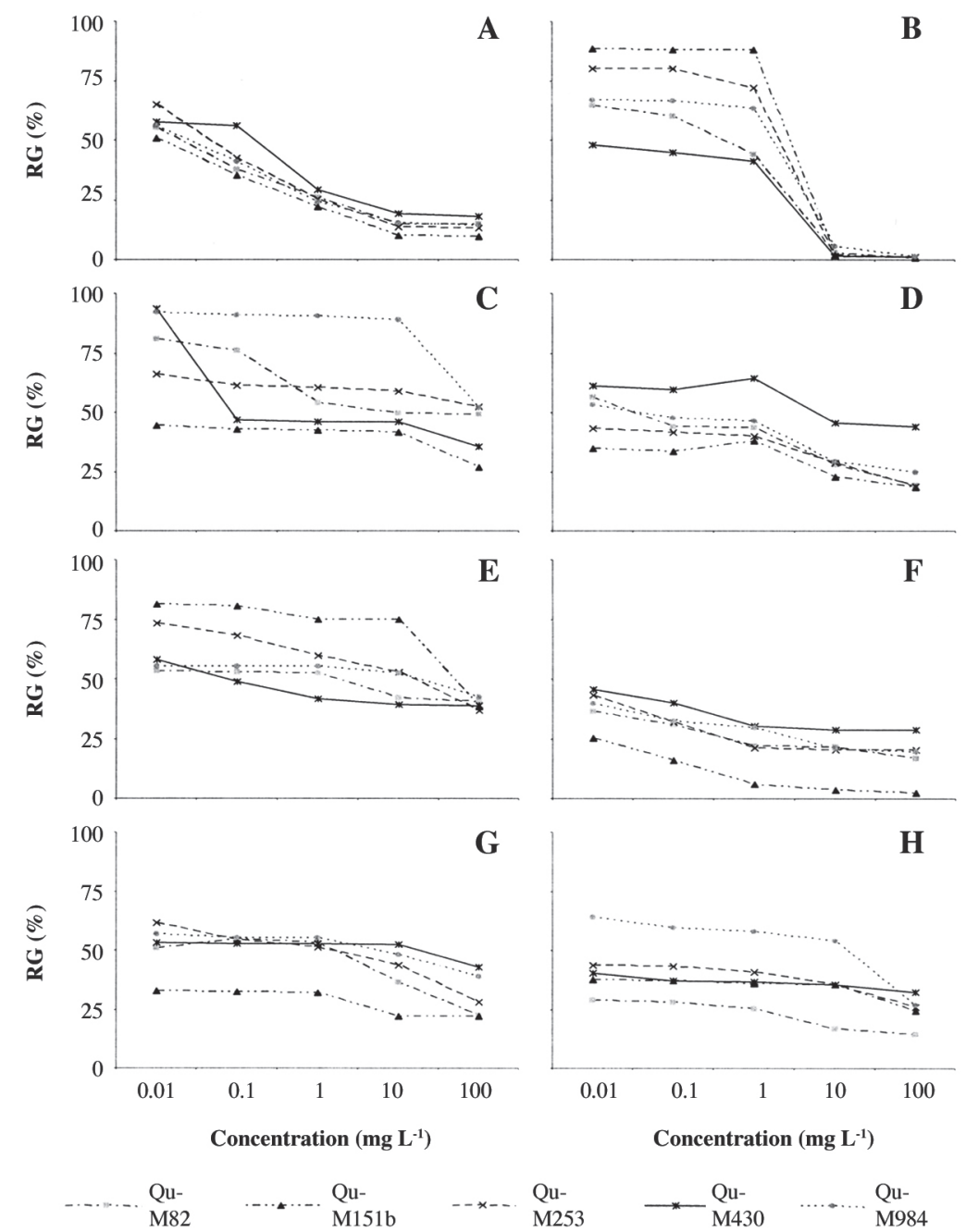

Figure 1. Colony relative growth (RG) of Metarhizium anisopliae var. anisopliae (Qu-M) isolates treated with different concentration of azoxystrobin (A), benomyl (B), captan (C), chlorothalonil (D), fenhexamid (E), fludioxonil (F), iprodione (G), and metalaxyl (H).

fungicides; however, these are only another indicator since the shape of each curve is different and with distinct extreme values for each one of them. Therefore, in addition to the value of AUGIC, it is also important to know the shape of the curve from which this value was obtained.

Qu-M430 was incompatible in all its benomyl concentrations and produced the lowest growth value (AUGIC $=2.64)$. The Qu-M82 isolate was incompatible beginning with $1 \mathrm{mg} \mathrm{L}^{-1}$ concentration and all the rest were incompatible starting from the $10 \mathrm{mg} \mathrm{L}^{-1}$ concentration. Hence, all isolates are affected at concentrations equal to or greater than $10 \mathrm{mg} \mathrm{L}^{-1}$ and almost entirely inhibit growth (Figure 1B). The highest growth value (AUGIC $=$ 4.17) was recorded for Qu-M151b (Figure 2B). Benomyl is in the benzimidazol group (nitro organic heterocyclic) characterized for inhibiting tubulin and impeding normal mitosis through the modification of the fungus cellular mechanism by competition with the free puric bases (adenine and guanine) or with formed nucleotides (Agrios, 2005). However, it is recognized that fungi exposed to this fungicide can suffer mutations that prevent the inhibitory effect of tubulin, mutations that can be found in nature, thus explaining the distinct growth values in $M$. anisopliae at the lowest benomyl concentrations. Similar results have been reported by Tedders (1981) and Alves et al. (1998) who point out that benomyl is incompatible with certain strains of M. anisopliae. Tamai et al. (2002) and Durán et al. (2004) also point out that benomyl affects plant development of EF B. bassiana while Rebollar et al. (1996) report that benomyl is incompatible with EF Verticillium lecanii. 

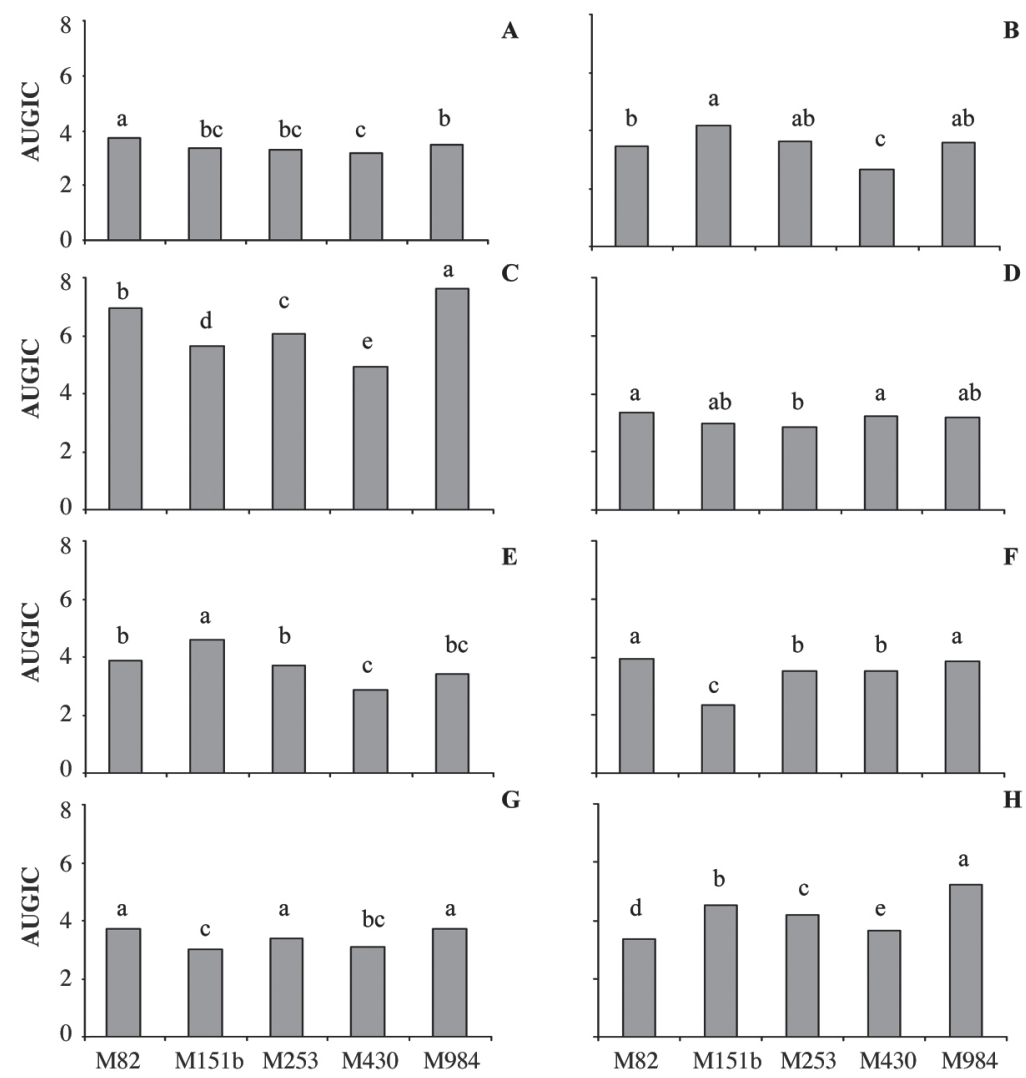

Different letters in bars and fungicide indicate difference in treatments according t-Student $(\mathrm{P}<0.05)$.

Figure 2. Area under growth inhibition curve (AUGIC) of Metarhizium anisopliae var. anisopliae (M) isolates treated with azoxystrobin (A), benomyl (B), captan (C), chlorothalonil (D), fenhexamid (E), fludioxonil (F), iprodione (G), and metalaxyl $(\mathrm{H})$.

Qu-M253 and Qu-M984 were compatible with all the captan concentrations while Qu-M151b was incompatible (Figure 1C). On the other hand, QuM430 was incompatible beginning with the $0.01 \mathrm{mg}$ $\mathrm{L}^{-1}$ concentration and Qu-M82 starting from $10 \mathrm{mg} \mathrm{L}^{-1}$. Captan was not effective for Qu-M984 and showed the highest growth rate (AUGIC $=7.62$; Figure $2 \mathrm{C}$ ) while $\mathrm{Qu}$ M430 was the lowest $(\mathrm{P}<0.05)($ AUGIC $=4.92)$. Captan is part of the dicarboximide group which impedes fungi respiration by interfering with Krebs cycle along with the inhibitory activity of sulfhydryl enzymes (Agrios, 2005). These arguments could explain isolate incompatibility for this active ingredient.

As regards chlorothalonil, the Qu-M151b and QuM253 isolates were incompatible for all concentrations (Figure 1D). Qu-M82 and Qu-M984 showed RGs less than 50 beginning with $0.1 \mathrm{mg} \mathrm{L}^{-1}$ chlorothalonil concentration while Qu-M430 showed RGs less than 50 starting from $10 \mathrm{mg} \mathrm{L}^{-1}$ (Figure 1D). These curves were different for the Qu-M82 and Qu-M253 isolates (Figure 2D). Chandler and Davidson (2005) reported the inhibitory action of chlorothalonil on $M$. anisopliae. This active ingredient is part of the chemical group of substituted aromatics (benzene derivative and isoftalonitril) acting on enzymes and hormones by inhibiting sulfhydryl radicals and other peptides, such as glutathione, during the germination process, disrupting glycolysis, and energy production (Agrios, 2005). However, Alves et al. (1998) point out that this product is compatibile with $M$. anisopliae which coincides with the Qu-M430 isolate response. This fungicide has also been reported to be compatible with other fungi such as B. bassiana (Durán et al., 2004). Fenhexamid was incompatible with all the isolates in the $100 \mathrm{mg} \mathrm{L}^{-1}$ concentration (Figure 1E). Qu-M151b, QuM253, and Qu-M984 were incompatible beginning with $10 \mathrm{mg} \mathrm{L}^{-1}$ while only Qu-M430 was incompatible at the $0.1 \mathrm{mg} \mathrm{L}^{-1}$ concentration. Qu-M430 (AUGIC = 2.88; Figure 2E) had lower growth for all concentrations. This active ingredient belongs to the hydroxianilide chemical group which acts on enzymes in different points of the 
sterol biosynthesis chain, but particularly on the C3 keto reductase enzyme (Hänbler and Pontzen, 1999). It is possible that this action mechanism has affected the evaluated strains; however, there are no known reports of the effect of fenhexamid on EF.

All M. anisopliae var. anisopliae isolates used in this bioassay were incompatible with the active ingredient fludioxonil at all the applied concentrations owing to the fact that none of the evaluated isolates showed $R G$ greater than or equal to 50 (Figure $1 \mathrm{~F})$. The lowest value $(\mathrm{P}<$ 0.05 ) for fludioxonil occurred with Qu-M151b (AUGIC $=2.88$ ) and the highest value with the Qu-M82 and QuM984 isolates (AUGIC $=3.94$ and 3.86, respectively) (Figure 2F). To date, no reports have been found on the action of fludioxonil on EF. This fungicide is characterized by its increase in glycerol synthesis (intercellular osmotic pressure regulating substance), provoking hypertrophy and blocking fungus cellular growth, a mechanism which could also have taken place in the M. anisopliae isolates used (Agrios, 2005; Kanetis et al., 2007).

Qu-M151b was incompatible with all the iprodione concentrations (Figure $1 \mathrm{G}$ ) and had lower relative growth values (AUGIC $=3.0$, Figure $2 \mathrm{G}$ ). The rest of the isolates were incompatible only beginning with the $10 \mathrm{mg} \mathrm{L}^{-1}$ concentration of iprodione (Figure 1G). These results coincide with those reported by Chandler and Davidson (2005) who point out that iprodione is incompatible with M. anisopliae. Rebollar et al. (1996) and Tamai et al. (2002) also point out that iprodione is incompatible with EF V. lecanii and B. bassiana, respectively.

As regards the active ingredient metalaxyl, Qu-M984 was only incompatible with the $100 \mathrm{mg} \mathrm{L}^{-1}$ concentration (Figure $1 \mathrm{H})$, showing the highest value $(\mathrm{P}<0.05)$ of AUGIC (5.22) (Figure 2H). The rest of the isolates were incompatible with all the evaluated concentrations (Figures $1 \mathrm{H}$ and $2 \mathrm{H}$ ). Although metalaxyl is not recommended to control hyphomycetes, in this case, an incompatibility effect of the product with colony growth was observed. Loureiro et al. (2002) had similar observations when they evaluated the effect of different products used in lettuce (Lactuca sativa L.) and chrysanthemum (Chrysanthemum morifolium L.) production, concluding that metalaxyl is not compatible with $M$. anisopliae. The mode of action of metalaxyl is to impede protein formation by interfering with the biosynthesis of nucleic acids and inhibit polymerase enzyme action in ribonucleic acid synthesis (Agrios, 2005). It is probable that this action mechanism can occur in fungi cultivated in vitro, but not necessarily for in situ conditions.

Effect of fungicides on conidia germination and germination tube length

It was possible to calculate the value of IC50 only for all the isolates incubated with benomyl, and only for $\mathrm{Qu}-$ $\mathrm{M} 151 \mathrm{~b}$ in the case of fludioxinil. The latter reached an IC50 of $0.02 \mathrm{mg} \mathrm{L}^{-1}$ of active ingredient while benomyl IC50 fluctuated between 2.4 and $4.9 \mathrm{mg} \mathrm{L}^{-1}$ for all evaluated isolates (Table 2).

Isolate germination percentages decreased in all cases from 61.7 to $91.3 \%$ for each benomyl IC50 in relation to the control $(\mathrm{P}<0.05)$ (Figure $3 \mathrm{~A})$. There are no references about germination effects of fungicides, except for the study by Durán et al. (2004) who point out that benomyl completely inhibits EF B. bassiana germination.

The response of isolates treated with benomyl was different when germination tube length was evaluated. The Qu-M253, Qu-M430, and Qu-M984 isolates did not show any differences in relation to the control (P $>0.05$ ) for tube length exposed to benomyl IC50, nor were deformations observed (Figure 3B). On the other hand, Qu-M82 and Qu-M151b did show differences (P $<0.05$ ) when benomyl IC50 was present, decreasing in length 36.6 and $18.5 \%$, respectively (Figure 3B). The fact that benomyl IC50 has affected normal germination development can be due to the mode of action of this active ingredient which was previously mentioned (Agrios, 2005). This inhibition probably generated a decrease in conidia germination and a decrease in germination tube length in those able to germinate, which in turn explains a decline in vegetative growth.

On the other hand, fludioxonil IC50 for the Qu-M151b isolate decreased conidia germination by $53 \%$ (Figure $4 \mathrm{~A}$ ) and germination tube length by $26.9 \%$ (Figure 4B) in relation to the control. The action mechanism of fludioxonil (Agrios, 2005; Kanetis et al., 2007) could be the cause of abnormal development of EF cells, in this way decreasing conidia germination, germination tube length, and therefore leading to lower vegetative growth.

The natural variability between isolates of the same species of $\mathrm{EF}$ is extensively described in the literature for biological parameters such as pathogenicity on an organism. Becerra et al. (2007) carried out an intraspecific differentiation with Random Amplified Polymorphic DNA (RAPD) markers, Simple Sequence

Table 2. Benomyl inhibitory concentration 50 (IC50) of Metarhizium anisopliae var. anisopliae $\mathrm{Qu}-\mathrm{M}$ isolates.

\begin{tabular}{lc}
\hline Isolates & IC50 benomyl \\
\hline & $\mathrm{mg} \mathrm{L}^{-1}$ \\
Qu-M82 & 2.9 \\
Qu-M151b & 3.4 \\
Qu-M253 & 2.4 \\
Qu-M430 & 2.9 \\
Qu-M984 & 4.9 \\
\hline
\end{tabular}




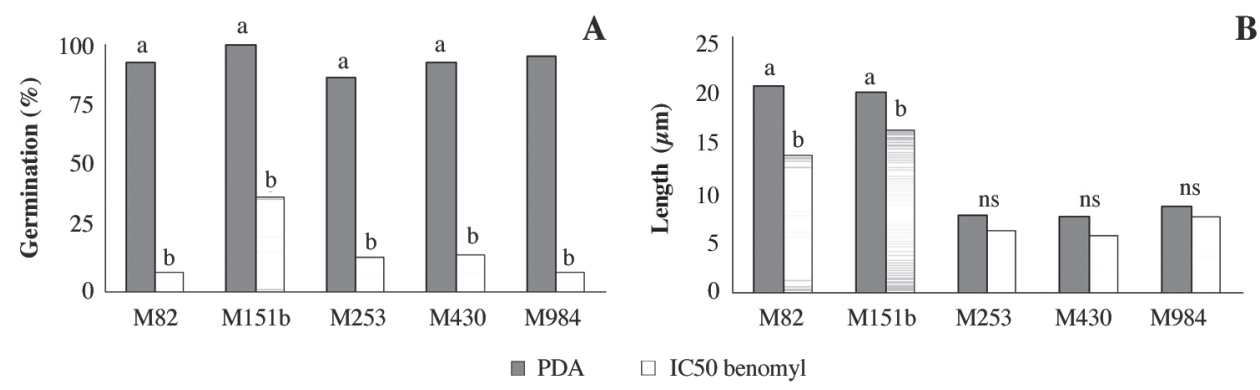

Different letters in bars and isolate indicate difference in treatments according t-Student $(\mathrm{P}<0.05)$.

Figure 3. Conidia germination (A) and germinative tube lengths (B) of Metarhizium anisopliae var. anisopliae (M) isolates with the inhibitory concentration 50 (IC50) of benomyl in potato dextrose agar (PDA).

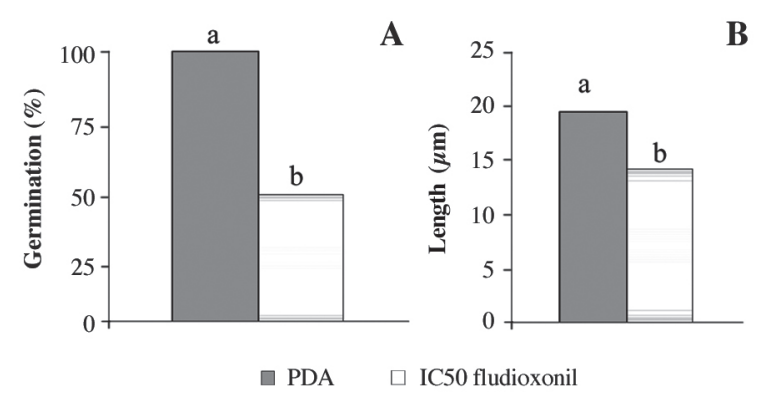

Different letters in bars and isolate indicate difference in treatments according t-Student $(\mathrm{P}<0.05)$.

Figure 4. Conidia germination (A) and germinative tube length (B) of Metarhizium anisopliae var. anisopliae Qu-M151b, with the inhibitory concentration $\mathbf{5 0}$ (IC50) of fludioxanil.

Repeats (SSR), and Internal Transcribed Spacers (ITS), concluding that genetic variability of INIA's EF collection combines three different genetic groups. Three of the five evaluated isolates in this bioassay were characterized by the aforementioned authors who concluded that the QuM151b, Qu-M253, and Qu-M430 isolates belong to the same genetic group; however, Qu-M253 and Qu-M430 would be more genetically similar than Qu-M151b. This variability could also explain sensitivity to synthetic chemical products (Alves et al., 1998). Furthermore, Inglis et al. (2006) point out that it is possible to select $\mathrm{EF}$ genotypes less susceptible to the fungicide action of agrochemicals. This is evidenced by observing the different responses among isolates as compared to the fungicides evaluated in this bioassay.

\section{CONCLUSIONS}

At the lower commercial doses of active ingredients used to control disease in berries, the benomyl and fenhexamid fungicides were compatible with the Metarhizium anisopliae isolates evaluated: Qu-M82, Qu-M151b, Qu-M253, Qu-M430, and Qu-M984. Azoxystrobin and fludioxonil were incompatible and therefore should be avoided in integrated pest management when some of these M. anisopliae isolates are used. The captan, chlorothalonil, iprodione, and metalaxyl fungicides showed different responses, so their action cannot be generalized for this entomopathogenic fungus. Fludioxonil and benomyl decreased conidia germination of evaluated $M$. anisopliae var. anisopliae isolates.

\section{RESUMEN}

Efecto de los fungicidas sobre el desarrollo del hongo entomopatógeno Metarhizium anisopliae var. anisopliae. Metarhizium anisopliae (Metschnikoff) Sorokin es un hongo entomopatógeno que se utiliza para el control de diferentes insectos, uno de sus usos más frecuentes es en frutales menores, donde también se utilizan fungicidas para el control de enfermedades. En este trabajo se evaluó el efecto de los fungicidas azoxystrobin, benomil, captan, chlorothalonil, fenhexamid, fludioxonil, iprodione y metalaxil, en concentraciones de 0,$01 ; 0,1$; 1; 10 y $100 \mathrm{mg} \mathrm{L}^{-1}$, sobre el crecimiento de la colonia, porcentaje de germinación de conidias y longitud de tubos germinativos de distintas cepas de $M$. anisopliae var. anisopliae. Las cepas utilizadas fueron Qu-M82, QuM151b, Qu-M253, Qu-M430 y Qu-M984, seleccionadas por su uso comercial para el control de diferentes insectos en frutales menores. El crecimiento se evaluó a través del diámetro de crecimiento de las colonias, considerándose como compatibles a aquellas que superaron el 50\% del crecimiento del testigo. Los resultados indicaron que los fungicidas benomyl y fenhexamid fueron compatibles con las cinco cepas, mientras que azoxystrobin y fludioxonil fueron incompatibles con todas las cepas evaluadas. Benomyl y fludioxonil además, disminuyeron (53 a 91\%) la germinación de conidias para los distintos aislamientos 
evaluados, así como la longitud de los tubos germinativos entre 18 y $37 \%$.

Palabras clave: control biológico, manejo integrado, crecimiento fungoso, germinación de conidias.

\section{LITERATURE CITED}

Agrios, G.N. 2005. Plant pathology. $5^{\text {th }}$ ed. p. 329-351. Elsevier Academic Press, San Diego, California, USA.

Alves, S.B., A. Moino, e J.E.M. Almeida. 1998. Produtos fitosanitários e entomopatógenos. p. 217-237. In S.B. Alves (ed.) Controle microbiano de insectos. Fundação de Estudos Agrários Luiz de Queiroz (FEALQ), Sao Paulo, Brasil.

Asociación de Exportadores de Chile. 2008. Fungicidas utilizados en berries permitidos en los mercados de Estados Unidos, Unión Europea y Japón. [Online]. ASOEX. Available at http://www.asoex.cl (accessed 3 April 2008).

Becerra, V., M. Paredes, C. Rojo, A. France, and J. Durán. 2007. Intraspecific differentiation of Chilean isolates of the entomopathogenic fungi Metarhizium anisopliae var. anisopliae as revealed by RAPD, SSR and ITS markers. Genetics and Molecular Biology 30:89-99.

Chandler, D., and G. Davidson. 2005. Evaluation of entomopathogenic fungus Metarhizium anisopliae against soil- dwelling stages of cabbage maggot (Diptera: Anthomyiidae) in glasshouse and field experiments and effect of fungicides on fungal activity. Journal of Economic Entomology 98:1856-1862.

Devotto, L., y M. Gerding. 2001. Plagas de los berries en la zona centrosur. Tierra Adentro (Chile) (36):12-14.

Durán, J., M. Carballo, y E. Hidalgo. 2004. Efecto de fungicidas sobre la germinación y el crecimiento de Beauveria bassiana. Manejo Integrado de Plagas y Agroecología (Costa Rica) 71:73-78.

France, A., M. Gerding G., M. Gerding P., y A. Sandoval. 2000. Patogenicidad de una colección de cepas nativas de Metarhizium spp. y Beauveria spp. en Aegorhinus superciliosus, Asynonychus cervinus y Otiorhynchus sulcatus. Agricultura Técnica (Chile) 60:205-215.

Flexer, J., and D. Belnavis. 2000. Microbial insecticides. p. 35-62. In Rechcigl, J.E., and N.A. Rechcigl (eds.) Biological and biotechnological control of insect pest. Lewis Publishers, Boca Raton, Florida, USA.

Fry, J. 1993. One - way analysis of variance. p. 1-40. In J.C. Fry (ed.) Biological data analysis a practical approach. Oxford University Press, New York, USA.

Hänbler, G., and R. Pontzen. 1999. Effect of fenhexamid on the development of Botrytis cinerea. PflanzenschutzNachrichten Bayer 52:158-176.
Infostat. 2002. Universidad Nacional de Córdoba. Córdoba, Argentina.

Inglis, G.D., M.S. Goettel, T.M. Butt, and H. Strasser. 2006. p. 23-70. In Butt, T.M., C. Janckson, and N. Magan (eds.) Fungi as biocontrol agents progress, problems and potential. CABI Publishing, London, UK.

Jobin, T., and O. Carisse. 2007. Incidence of myclobutaniland kresoxim-methyl-insensitive isolates of Venturia inequalis in Quebec orchards. Plant Disease 91:13511358.

Kanetis, L., H. Förster, and J.E. Adaskaveg. 2007. Comparative efficacy of the new postharvest fungicides azoxystrobin, fludioxonil, and pyrimethanil for managing citrus green mold. Plant Disease 91:1502-1511.

Kaya, H., and L. Lacey. 2007. Introduction to microbial control. p. 3-7. In Lacey, L.A., and H. Kaya (eds.) Field manual of techniques in invertebrate pathology application and evaluation of pathogens for control of insects and other invertebrate pests. Springer, Dordrecht, The Netherlands.

Khetan, S. 2001. Mycoinsecticides. p. 211-222. In Microbial pest control. Marcel Dekker Inc., New York, USA.

Köller, W., and W.F. Wilcox. 2001. Evidence for the predisposition of fungicide- resistant isolates of Venturia inaequalis to a preferential selection for resistance to other fungicides. Phytopathology 91:776-781.

Lennox, Ch., and R. Spotts. 2003. Sensitivity of populations of Botrytis cinerea from pear- related sources to benzimidazole and dicarboximide fungicides. Plant Disease 87:645-649.

Loureiro, E. de S., A. Moino, A. Arnosti, e G.C. De Souza. 2002. Efeito de produtos fitosanitários químicos utilizados em alface e crisântemo sobre fungos entomopatogènicos. Neotropical Entomology 31:263-269.

NIS Elements. 2006. Imaging software. Version D2.3, Laboratory Imaging, Nikon Instruments Inc., Melville, New York, USA.

OrigenPro. 2003. Version 7.5. Origen Lab Corporation, Northampton, Massachusetts, USA.

Rebollar, A., R. Latorre, y C. Mendoza. 1996. Evaluación in vitro de fungicidas sobre el hongo entomopatógeno Verticillium lecanii (Zimm.) Viegas. Revista Chapingo serie: Protección Vegetal (México) 3(1):41-44.

Samson, P., R. Milner, E. Sander, and G. Bullard. 2005. Effect of fungicides and insecticides applied during planning of sugarcane on viability of Metarhizium anisopliae and its efficacy against white grubs. BioControl 50:151-163. 
Tamai, M., S.B. Alves, R.B. Lopes, M. Faion, e L.F.L. Padulla. 2002. Toxicidade de produtos fitossanitários para Beauveria bassiana (Bals.) Vuill. Arquivosdo Instituto Biológico 69(3):89-96.

Tedders, W.L. 1981. In vitro inhibition of the entomopathogenic fungi Beauveria bassiana and Metarhizium anisopliae by six fungicides used in pecan culture. Environmental Entomology 10:346349.
Tremblay, D.M., B.G. Telbot, and O. Carisse. 2003. Sensitivity of Botrytis squamosa to different classes of fungicides. Plant Disease 87:573-578.

Ypema, H.L., and R.E. Gold. 1999. Kresoxim-methyl modification of a naturally occurring compound to produce a new fungicide. Plant Disease 83:4-19. 